\title{
Metal in the design of public transport stops
}

\author{
Liliia Gnatiuk ${ }^{1 *}$ and Hanna Novik ${ }^{1}$ \\ ${ }^{1}$ National Aviation University, Department of interior design, Kyiv - 58, 03680, Ukraine
}

\begin{abstract}
Public transport stops as special architectural forms in the urban environment are reviewed. Based on the analysis of foreign analogues, in accordance with the expressive means, the existing projects of stops are classified into subspecies as artistic, thematic, ecological and futuristic. As a result of the research, the conclusion is made about the influence of certain factors on the formation of pavilions: 1) the need to implement the priority requirements of different level users to the spatial planning structure of the stop complex, such as: transparency, control, protection, safety, accessibility, information, rational use of space, comfort and services; 2) the character of the building; 3) ecology requirements; 4) used structural and decoration materials; 5) national traditions; 6) aesthetic tastes and preferences of citizens and city administration; 7) climate conditions. The use of metal (steel, aluminum, and constructive principles of collection require corresponding design approaches. It is necessary to find a specific stylistic solution, which, being repeated many times, will create a system of visual accents along the urban transport route. The appropriate design would turn public transport stops into potential accents of the urban environment, the analogues of urban sculpture, which not only fulfil their daily necessary function and contain the most modern electronic means of information and control, but also contribute to the emotional comfort of passengers.
\end{abstract}

\section{Introduction}

The condition of public transport stops nowadays is a problematic issue for the capital of Ukraine in the context of the country's European development vector [1]. Reforming the public transport system is relevant for major cities of the world and is aimed at the solution of similar problems: increasing safety and reducing the intensity of traffic, fighting noise level and air pollution, full and qualified fulfilment of the city population's need for transportation. The main goal if the increase the productivity of public transport in comparison with the growth of light-duty vehicle traffic volume.

The solution of this problem is possible if the city inhabitants will consider a trip in public transport competitive comparing to a light-duty vehicle trip. According to the research [2], the competitiveness of public transport travel is estimated by the user based on a number of criteria, including the condition of stops as an integral part of using the public transport system. At the same time, the design of the stop pavilions is a particular problem.

* Corresponding author: gnatyuk.liliya@gmail.com 
Today, public transport stops according to the data of "Kyivpastrans" [3] do not fully satisfy the needs of passengers - they are obsolete, worn out, uncomfortable and nonfunctional, and do not meet the aesthetic requirements. The problem is also the unauthorized placement of temporary structures for doing business on the territory of the stops, which overloads the pedestrian zone and does not allow unimpeded access to transport. In many cases, the number of these outlets that often sell cigarettes and alcohol grows so much that the stop itself is lost among them.

Due to a complex of advanced mechanical, technological and artistic qualities, metals and alloys are widely used for the equipment and decoration of the urban environment and the stop complexes in particular. However, the possibilities of the forming a metal are diverse. Depending on the manufacturing technology, metal structures allow to create a wide range of visual impressions, while the material becomes an influencing factor for the formation of the object. In this case, the requirements for the design of the stops must be coordinated with the necessary and sufficient possibilities for the formation of metal.

Thus, the replacement of worn out and non-functional stops of public transport is an important task for many cities in Ukraine. In this regard, it is crucial to identify the requirements for their design in order to create aesthetically attractive and comfortable places to wait for public transport. The relevance of the conducted research consists of revealing the approaches of forming the volumetric-spatial structure and art image of city public transport stops.

\section{Methods}

The method of theoretical research of material consists of collecting data in the selected theme, its classification, generalization of each of the groups, typologization and evaluation of identified essential characteristics of objects.

\section{Results}

According to the definition [4], public transport stops are a set of amenities for organized waiting, landing and boarding of route vehicles passengers. The waiting pavilion is one of the elements of this complex. On the one hand, these objects belong to engineering road structures and on the other hand to small architectural forms. In the conditions of the city, these elements are the compositional details of the environment, an intermediate link in the scale correlation between a human and a building.

At the same time, the equipment of the stop is the part of object-spatial environment the direct surrounding of the person. Therefore, the pavilion design of the public transport stop should satisfy the dual task of creating harmonious conditions for human stay and fitting into the surrounding urban environment. The first task can be solved by taking into consideration the needs of passengers, vehicle drivers, shipping companies and city administration during the design process.

According to the research [6-15], the priority requirements of users for the stop complex are the following: transparency, control, protection, safety, accessibility, information, rational use of space, comfort and services. From this list it is possible to select the requirements relating to the formation of the volumetric-spatial structure of the pavilion (Table 1). At the level of forming the waiting pavilion, these requirements are realized by the following elements.

The requirements of transparency, protection, rationality are best satisfied when using metal as a structural material while being implemented into the design of the stop. The differentiation of waiting pavilions in terms of capacity and modularity of the structure are 
easily achieved by installing a steel frame with high-strength glass combined with composite materials.

The formation of the pavilion is determined by the implementation of the stated requirements in combination with the solving the aesthetic task of inscribing the object into the urban environment. While solving this problem, certain questions arise, which, in particular, are the subject of public discussion. Optimally fitting into the environment, the stops in some cases are able to emphasize its character (historical, modern), in other cases, on the contrary, they can create specific accents for changing the character of the building, increasing its comfort and expressiveness.

Table 1. Implementation of user requirements in the design of the pavilion

\begin{tabular}{|c|c|c|}
\hline Requirement & Justification & $\begin{array}{l}\text { Implementation in the design } \\
\text { of the pavilion }\end{array}$ \\
\hline Transparency & $\begin{array}{l}\text { Providing a good view of the } \\
\text { road to passengers at the stop, } \\
\text { passers-by and drivers. The } \\
\text { accessibility of the view to } \\
\text { architectural elements of } \\
\text { buildings and streets }\end{array}$ & $\begin{array}{l}\text { The use of transparent materials, planning } \\
\text { structure that provides access to natural } \\
\text { light, good artificial lighting }\end{array}$ \\
\hline Control & $\begin{array}{l}\text { Providing minimal time for } \\
\text { orientation and control of } \\
\text { transfer }\end{array}$ & $\begin{array}{l}\text { Placement of necessary signs and indexes } \\
\text { taking into account ergonomic } \\
\text { requirements for maximum availability }\end{array}$ \\
\hline Information & $\begin{array}{l}\text { Ensuring a minimum time for } \\
\text { deciding on further action }\end{array}$ & $\begin{array}{l}\text { Equipment of stops with electronic } \\
\text { displays with information on the location } \\
\text { of buses and maps of routes. }\end{array}$ \\
\hline $\begin{array}{l}\text { Protection, } \\
\text { comfort }\end{array}$ & $\begin{array}{l}\text { Ensuring the protection of } \\
\text { passengers while waiting for } \\
\text { transport from the influence of } \\
\text { adverse weather conditions. }\end{array}$ & $\begin{array}{l}\text { Roof, rear and side walls. Use of materials } \\
\text { with anti-vandal protection. Presence of a } \\
\text { bench. }\end{array}$ \\
\hline Safety & $\begin{array}{l}\text { Reducing the number of } \\
\text { crimes }\end{array}$ & $\begin{array}{l}\text { Creating a space-planning structure that } \\
\text { excludes isolated spaces }\end{array}$ \\
\hline $\begin{array}{ll}\text { Land } & \text { use } \\
\text { rationality } & \end{array}$ & $\begin{array}{l}\text { Different sections of roads } \\
\text { require pavilions of different } \\
\text { sizes }\end{array}$ & $\begin{array}{l}\text { Differentiation of pavilions of waiting by } \\
\text { capacity and layout. Modular design. }\end{array}$ \\
\hline Services & Enhanced functionality & $\begin{array}{l}\text { Pavilions can be equipped with automatic } \\
\text { ticket sales, garbage cans, toilets }\end{array}$ \\
\hline Advertising & $\begin{array}{l}\text { Sale of advertising allows to } \\
\text { pay for maintenance work at } \\
\text { the stop }\end{array}$ & Advertising construction \\
\hline
\end{tabular}

The requirements of correspondence of the stops as small architectural forms to the surrounding urban buildings and the suggested similarity of the pavilions around the city seem to be in clear contradiction [16]. Both stylistically and qualitatively many city districts are very different from each other, the visual series facing the roadway in the historical centre of the city do not look like the visual series in the industrial zone or residential area.

The only way that would allow making the stylistically similar objects that would correspond with such different surroundings is to design them as faceless as possible, 
without singularities, and therefore imperceptible. But in the first place, public transport stops must fulfil their direct function, and if such object is invisible, then the passengers are more difficult to navigate, especially in an unfamiliar area.

Consideration of public transport stops as a unique architectural form could, on the contrary, diversify the urban environment, especially in those parts of the city where the buildings are not distinguished by architectural expressiveness. In a state of a crisis, when it is difficult for the city to afford installation of special art objects as decoration, the public transport stop, as the existing necessary elements of urban infrastructure, could become a noticeable and interesting accent of urbanization.

This approach has recently been developing in different countries [17]. Review of existing stops shows that these buildings can be turned into real works of architectural and design art (Fig. 1).

Regarding the design of stops of this type, metal is used as artistic material created with the help of traditional technologies, such as casting and art forging, which are used to obtain unique objects.

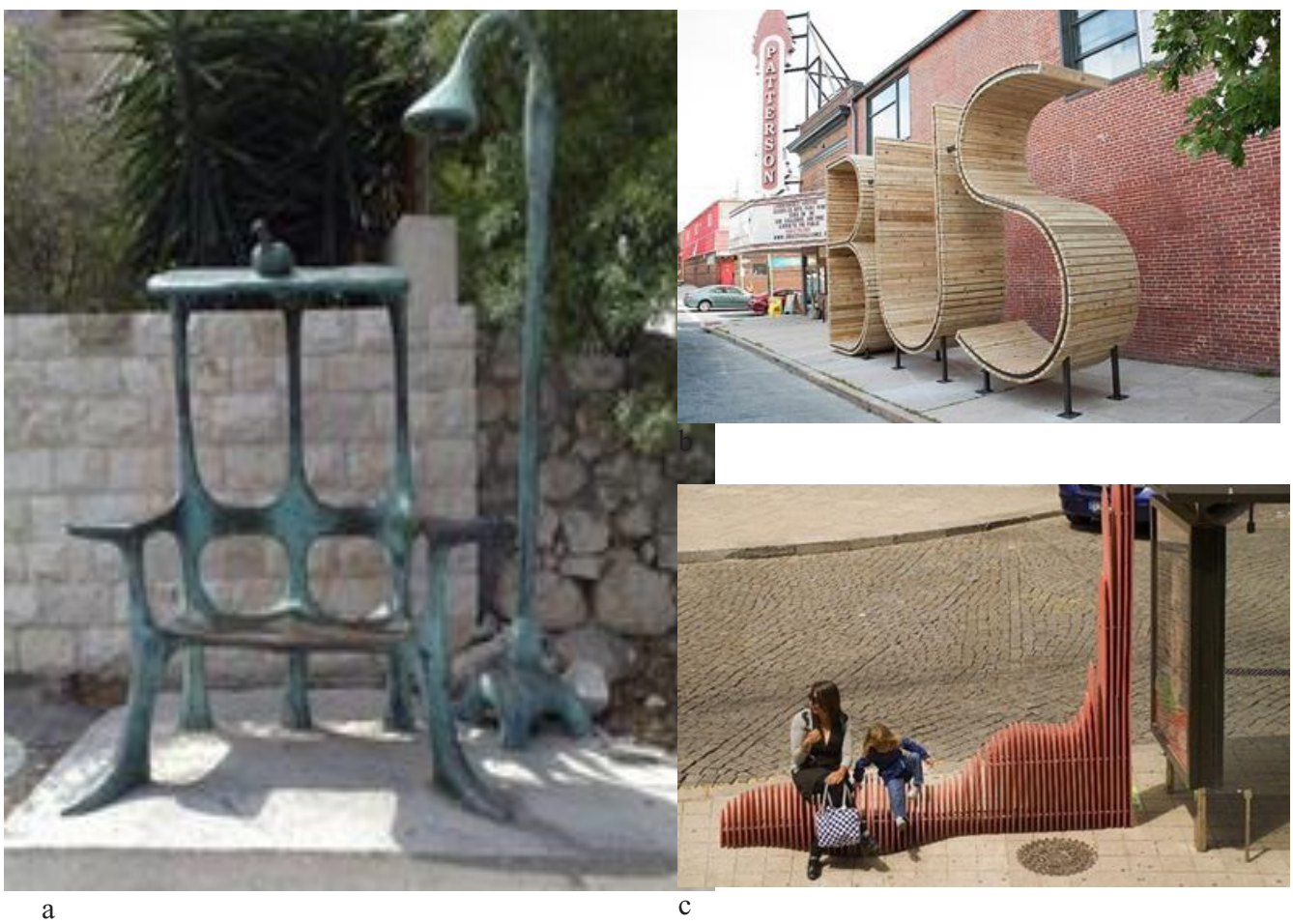

Fig. 1. Bus stops as an art object: a - cast sculpture, Israel; b - stop in Baltimore, USA; c - Portugal, the company "Like Architects".

In some cases, the humorous and ironic approach may be embodied in the design concepts of the stops. In the world practice, stops are more often becoming thematic, for example, they are reflecting famous feature and animation films, look like small houses or amaze by the extravagance and boldness of artistic concept (Fig. 2).

As for the stops of this type, constructions are created with the help of modern technologies - stamping, milling, physical and mechanical methods of cutting, etc. These means allow to widen compositional and layout abilities. There is also a hidden use of metal - as an armature for objects built using other technologies. 

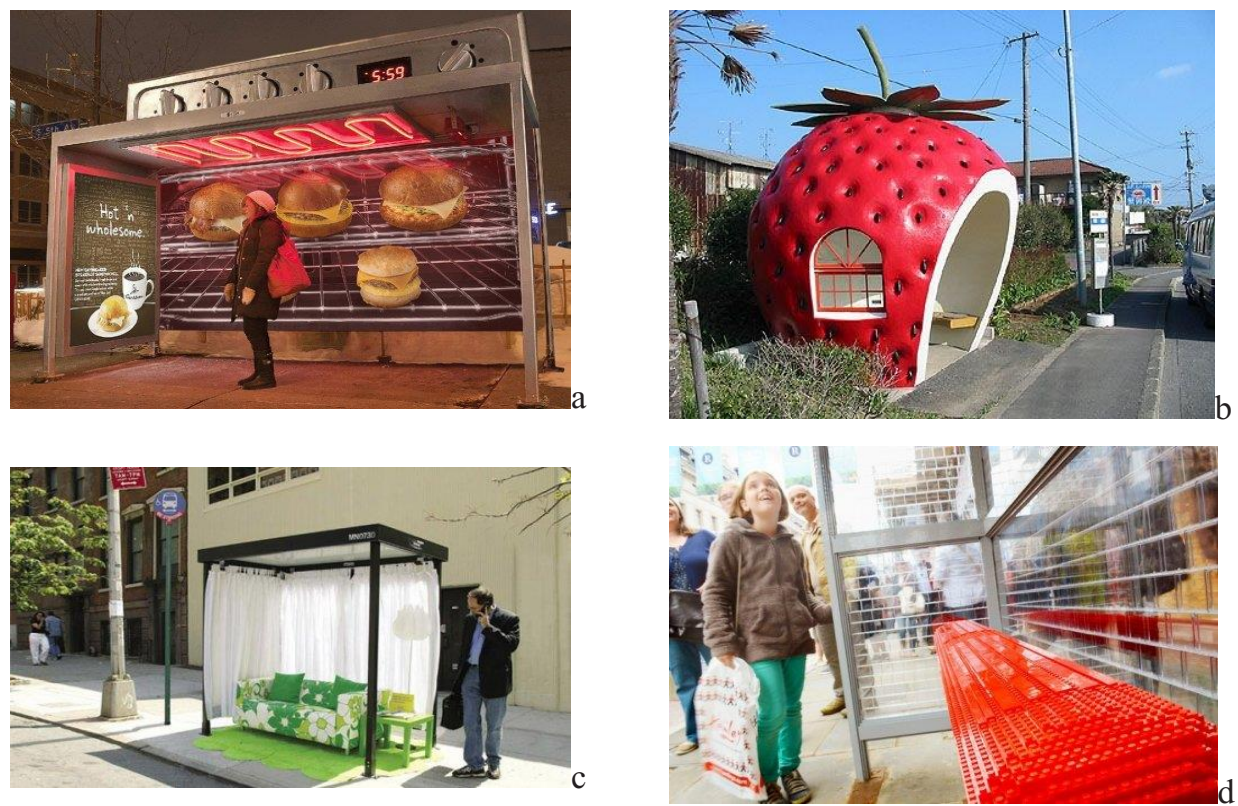

Fig. 2. Thematic bus stops: a - oven-stop, Minnesota, USA; b - stops in the form of fruits and vegetables, Konagai, Japan; c - stop from IKEA, New York, USA; d - stop from LEGO at Regent Street, London, England.

The modern tendency towards an ecological approach to design finds its embodiment in the projects of greened stops, which is especially actual use in the conditions of "stone jungles" (Fig. 3).

It should be noted that in the structures of the "ecological" group, metal structures are used as a supporting framework. Formation of the metal here is neutral, geometric, with its severity it contrastingly emphasizes the liveliness of plant forms. It is used parts in the form of pipes, rods of different cross-section, rolling, ropes.
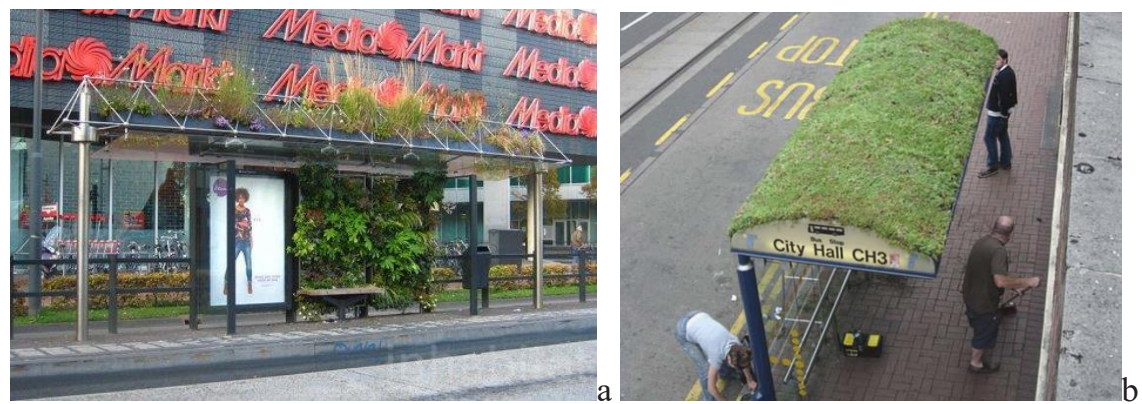

Fig. 3."Ecological" bus stops: a - stop with a vertical garden from the company WVTTK Architects, Eindhoven, the Netherlands; b - Green Roof Bus Stop, England.

Along with thematic, imaginative solutions, there are projects that are extremely minimalistic, realized in the style of hi-tech, using as means of expression characteristic lines, a futuristic imagery of the form associated with speed and movement (Fig. 4).

The shining and plasticity of metal is associated with modern technologies and it finds here its most expressive embodiment. 

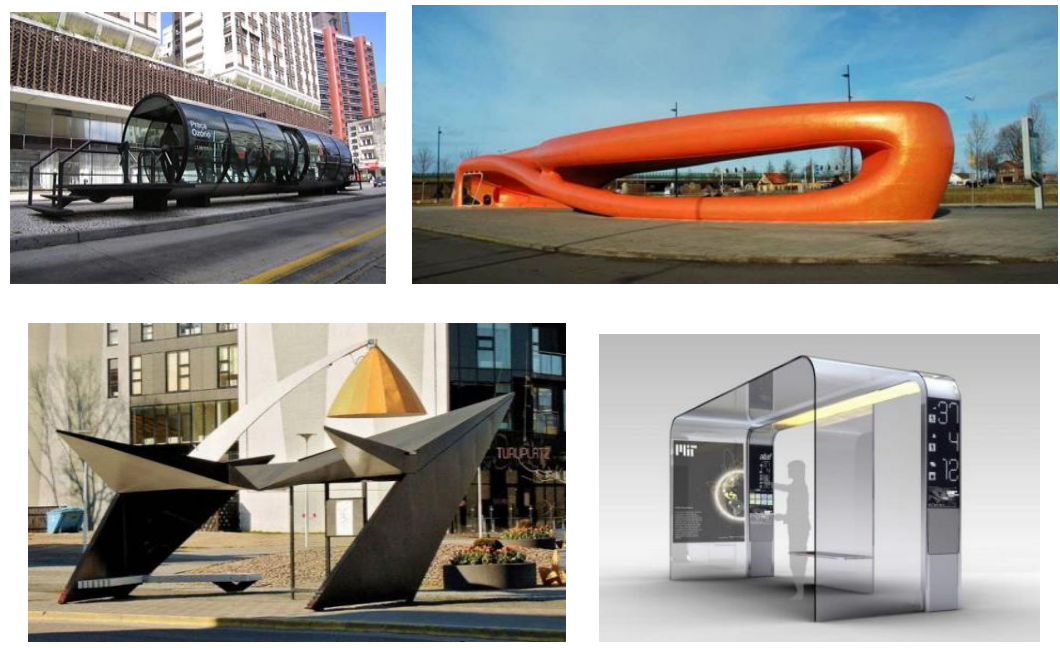

Fig. 4. Futuristic imagery of the form.

In areas with historical buildings, waiting pavilions usually become the high-tech functional elements of the city (Fig. 5). Minimalistic design will highlight the stop due to the contrast with the forms of historical environment. However, the pavilions should be noticeable, making it easier for residents and tourists to orient among the city attractions.

Metal is being used for design of the stops of this type most often. The same as with in the stops of the "futuristic" group, the composition is built on geometric forms, straight lines or with minor radius. The stop becomes noticeable due to accented elements, lighting, information and advertisement units.
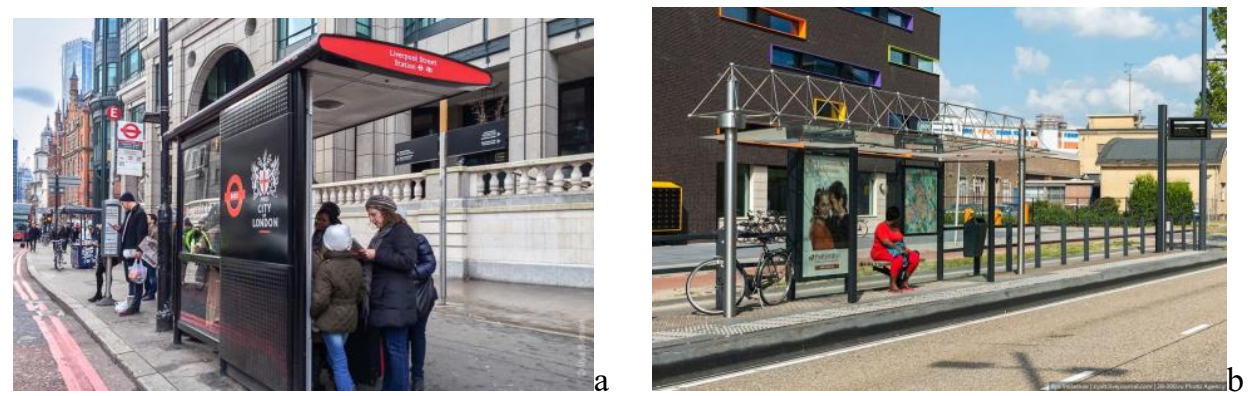

Fig. 5. "High-tech" bus stops: a - stop "Station Liverpool Street" in the City, London; b - Eindhoven, Netherlands

It is not difficult to see that the volume-planning structure and the formation of stops of the first and partially second types do not satisfy the requirements shown in Table 1 . In these pavilions, as in any art objects, the figurative component prevails over the utilitarian one. Such stops can be single cases which contribute to the improvement of the city's psychological climate, including the element of the game. Besides, major advertisement companies consider such creative stops as one of the most important advertising mediums.

\section{Discussion}

Thus, in accordance with the expressive means used, existing projects of stops can be classified as: artistic, thematic, ecological, futuristic and technological. In each of the groups, the formation features are determined by the ratio of artistic image and utilitarian 
component. The appropriate design will turn the public transport stops into the potential accents of urban environment, analogues of urban sculpture, which not only fulfil their daily necessary function and contain the most modern electronic means of information and control, but also contribute to the emotional comfort of passengers.

The conducted analysis reveals that it is possible to embody a wide variety of images and idea sin the design of a public transport stop, including those relevant to modern Ukrainian society. An imaginative expression of the idea of national unity by addressing to ethnic motives in design can be an interesting and actual challenge for domestic designers. The creation of a project that would combine national priorities features of modern formbuilding and the necessary requirements for optimizing construction costs will be a significant step towards approaching the implementation of world experience in the passenger service at public transport stops.

\section{Conclusions}

The following factors can influence the forming of public transport waiting pavilions: 1) the implementation of priority requirements of different level users in the spatial planning structure of the stop complex, such as: transparency, control, protection, safety, accessibility, information, rational use of space, comfort and services; 2) the character of the building; 3) ecological requirements; 4) used structural and decoration materials; 5) national traditions; 6) aesthetic tastes and preferences of citizens and city administration; 7) climate conditions.

The use of metal (steel, aluminum, ) and constructive principles of collection require corresponding design approaches. It is necessary to find a specific stylistic solution, which, being repeated many times, will create a system of visual accents along the urban transport route. It was revealed that the project should include the creation of a bright image with national motives, combining reliable protection of passengers from adverse weather conditions, ergonomic literacy and modern information equipment.

\section{References}

1. URL: http://kga.gov.ua/rss/199-kontseptsiya-rozmishchennya-zupinok-gromadskogotransportu-v-kievi/

2. M.M. Lambuts'kiy, PhD Thesis (Kiyiv, 2007)

3. Ukrainian State Standard KDP-204/12 Ukrajina 240-95

4. Ukrainian State Standard DBN V.2.3-5-2001

5. URL: www.bctransit.com/corporate/resources/pdf/res-urban-21.pdf.

6. URL: https://at.govt.nz/media/imported/4394/Public_Transport_Interchange_Design_Guideli nes.pdf

7. Florida Department of Transportation, District 4, Transit Facilities Guidelines. 3rd Version, October (2007)

8. American Association of State Highway and Transportation Officials. Guide for Planning, Design and Operation of Pedestrian Facilities. Washington, D.C., (2004)

9. References American Association of State Highway and Transportation Officials. A Policy on Geometric Design of Highways and Streets. Washington, D.C., (2004)

10. Amtrak Station Manual-Station Program and Planning: Standards and Guidelines. Amtrak Inc. Version 1.2, (2001) 
11. URL: https://ageconsearch.umn.edu/bitstream/206964/2/2121-4176-1-PB.pdf Vol. 47, No. 3 pp. 7791 (2008)

12. Federal Highway Administration, Manual on Uniform Traffic Control Devices (MUTCD), (2003)

13. Florida State University. Design Handbook for Florida Bus Passenger, Facilities: Accessing Transit. Department of Urban and Regional Planning - Florida Department of Transportation, Public Transit Office, (2004)

14. Miami-Dade County Transit. Rapid Transit System Extensions Compendium of Design Criteria. Volume II. Station Design Criteria, 2007.

15. W.F.E. Preiser,, \& E. Ostroff. Universal Design Handbook. (McGraw-Hill, New-York, 2001)

16. L.S. Filatov, PhD Thesis (Moscow, 2004)

17. URL: http://www.bugaga.ru/pictures/geo/1146745313-samye-neobychnye-avtobusnyeostanovki.html/ (Data obrashcheniya: 18.03.2016) 